Ethiopian Journal of Environmental Studies \& Management 10(3): 299 - 314, 2017.

ISSN: 1998-0507

doi: https://dx.doi.org/10.4314/ejesm.v10i3.3

Submitted: December 07, 2016

Accepted: April 07, 2017

\title{
ANTHROPOGENIC IMPACTS ON THE WATER QUALITY OF ABA RIVER, SOUTHEAST NIGERIA
}

\author{
AMAH-JERRY, E.B., *ANYANWU, E.D. AND AVOAJA, D.A. \\ Department of Zoology and Environmental Biology, Michael Okpara University of \\ Agriculture, Umudike, Nigeria
}

\begin{abstract}
A stretch of Aba River, southeast Nigeria was studied in four stations from November 2014 to August 2015 to identify the major anthropogenic activities and their impact on the water quality. A number of major anthropogenic activities were identified; some were regular and persistent such as washing of clothes, rugs/carpets and cars as well as effluents and wastes from abattoir. Dredging was observed as a one-time anthropogenic activity during this study with its associated impacts. The identified anthropogenic and other salient activities in the watershed have individually and cumulatively impacted on the water quality of Aba River. Some of the water quality parameters had elevated values but the most affected were turbidity (6.8 - 321NTU/FEPA, 10NTU), phosphate (2.3 $79.8 \mathrm{mg} / \mathrm{l} / \mathrm{FEPA}, 5 \mathrm{mg} / \mathrm{l})$ and nitrate $(7.4-79.8 \mathrm{mg} / \mathrm{l} / \mathrm{FEPA}, 20 \mathrm{mg} / \mathrm{l})$. These observed impacts on the water quality have directly or indirectly affected the ecological, domestic and other uses of the river. Many residents cannot use the water for drinking, cooking, industrial or aquaculture purposes.
\end{abstract}

Key Words: Physico-chemical parameters, Watershed, Cumulative impact

\section{Introduction}

Anthropogenic activities result in significantly decrease of surface water quality of aquatic systems in watersheds (May et al., 2006). Rivers in a watershed play a major role in assimilating or carrying off municipal and industrial wastewater and runoff from agricultural land (Wang et al., 2007). Therefore, a river is a reflection of its watershed. River inflows contribute main pollutants to most lakes in a watershed, thereby tending to induce serious ecological and sanitary problems (Gilbert and Wendy, 2003; Kunwar et al., 2005). On the other hand, rivers constitute the main water resources for domestic, industrial, and irrigation purposes in a watershed ( $\mathrm{Yu}$ and Shang, 2003). Pollution of surface water bodies, resulting from anthropogenic activities, is a growing concern worldwide (Zhai et al., 2014; Hillel et al., 2015). Thus it is imperative to prevent and control river pollution and to have reliable information on the quality of water for effective management (Wang et al., 2007). For most watersheds with greatly varying topographical conditions, the water quality of rivers is characterized by a

*Corresponding Author: Anyanwu, E.D.

Email: ekadon@yahoo.com 
high degree of heterogeneity in space and time, due to the variety of land cover around them. This often makes it difficult to identify water conditions and pollution sources, which is necessary for effective pollution control and water resource management (Kunwar et al., 2005). In Nigeria, many streams and rivers, particularly those in urban and semi urban cities, get polluted as a result of the discharge of untreated wastewater and other organic wastes directly into them (Jaji et al., 2007; Osibanjo et al., 2011; Anyanwu, 2012). Thus, river pollution is becoming a central issue in water management in Nigeria (Arimoro, 2009). Available reports cite gross contamination of most major rivers across Nigeria by discharge of industrial effluents, sewage and agricultural wastes among others (World Bank, 1995). The objective of the present study was to identify the anthropogenic activities and their impacts on the water quality of Aba River, Aba, Southeast Nigeria.

\section{Methodology}

\section{Study Area and Sampling Stations}

Ogbor community constitutes the study area and is situated in Aba, a commercial city of Abia state, Nigeria. The River, which lies between latitude $5^{\circ} 05^{\prime}$ to $5^{\circ} 30^{\prime}$ North and longitude $7^{\circ} 15^{\prime}$ to $7^{\circ} 40^{\prime}$ East, is a tributary of Imo River and transverse Aba town (Fig. 1). The river originates from the northern $\mathrm{Ngwa}$ hinterland of Aba, cutting through different local governments areas in Abia State and discharge into Ikot Abasi/Opobo, from where it empties with its creeks into the Atlantic Ocean. The vegetation appears more forest-like along river channels and due to intense farming in the area; grasses are taking over the original tropical forest characteristic of the area. The river receives wastes from a number of activities going on in the watershed.

Station 1 is upstream, located in Okpulor - Umuobu area of Aba. It is open and the substrate was muddy with minimal human activities. The major activities observed were children engaged in fishing with hook and line, swimming, washing of clothes and cars. Station 2, also located in Okpulor - Umuobu area, under the bridge, $44 \mathrm{~m}$ downstream of station 1. It is also open with muddy substrate. Activities include washing of clothes and large scale washing of rugs, carpets and cars. Station 3 is located in Ogbor Hill area of Aba, about $4.17 \mathrm{~km}$ downstream of station 2 with muddy substrate. Abattoir wastes and effluent are discharged here. Station 4, also located around Ogbor Hill area, about $256 \mathrm{~m}$ downstream of station 3 with muddy substrate. It is close to built-up and residential area with no observed human activities during the study.

\section{Samples Collection and Analyses}

Water samples were collected from Aba River monthly from November 2014 to August 2015. Samples were collected with 1 litre water sampler and stored in sterilized 1litre plastic bottles. Water temperature, $\mathrm{pH}$, conductivity and total dissolved solids were determined in situ using Hanna Portable Meter (HI9811-5), before the samples were taken to the laboratory for analysis. The physicochemical parameters were analyzed using standards methods described by American Public Health Association (APHA) (1998). All the results were statistically analysed using ANOVA and Tukey's pairwise comparisons test was performed to determine the location of significant difference (Ogbeibu, 2005). 


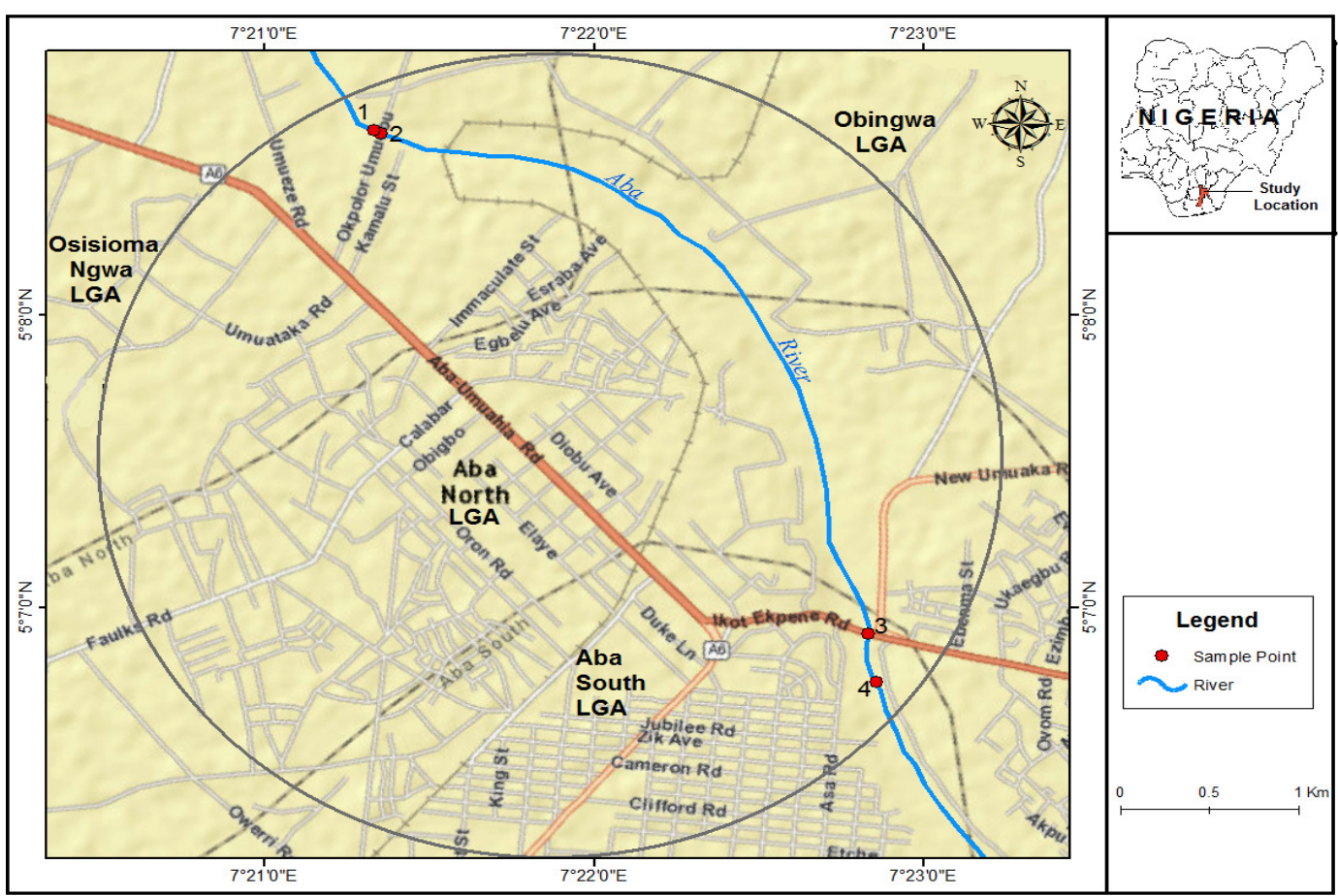

Fig. 1: Map of Aba, Southeast Nigeria showing the sampling stations of Aba River

\section{Results}

The summary of physicochemical parameters is presented in Table 1 while the spatial and temporal variations in the parameters are presented in Figs. 2 - 13. The Surface water temperatures ranged from $23.5^{\circ} \mathrm{C}$ to $30.1^{\circ} \mathrm{C}$. The water temperature trend showed that the values were generally higher in Station 3 (Fig. 2) and significantly different $(\mathrm{F}=10.9, p$ $<0.05)$ in all the stations. The temperature values recorded in this study are within the acceptable limit of $40^{\circ} \mathrm{C}$ set by FEPA (2003).

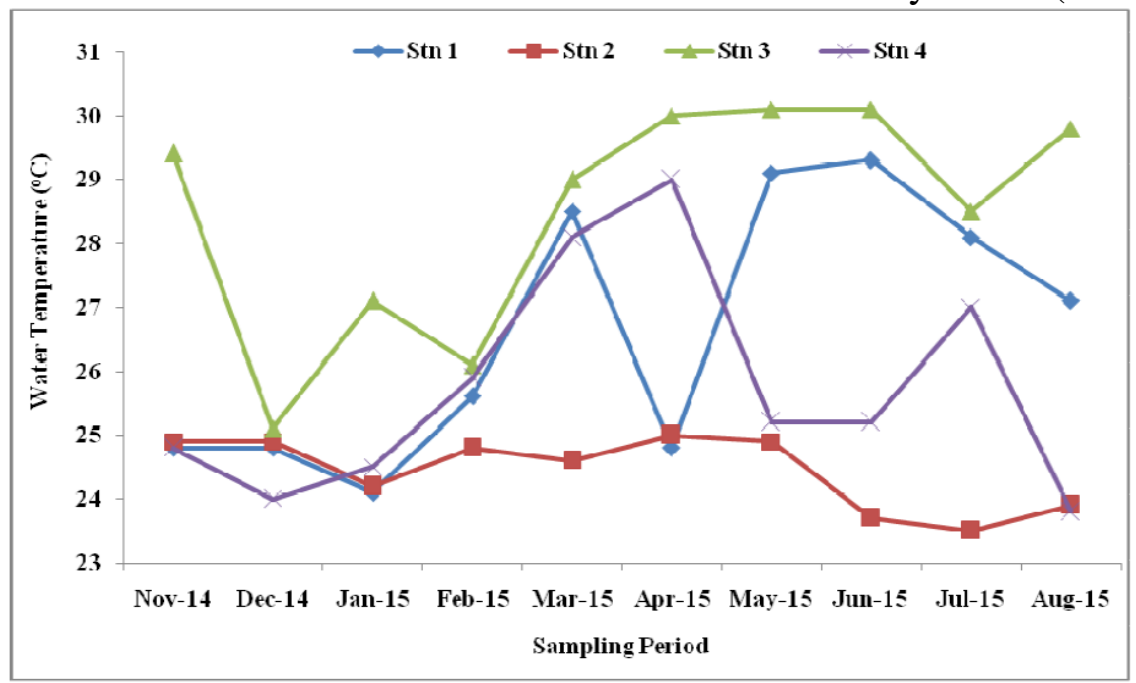

Fig. 2: Spatial and temporal variations in Water Temperature at the study stations in Aba River 
Table 1: Summary of Physico-chemical Parameters of Aba River (with range in Parenthesis)

\begin{tabular}{|c|c|c|c|c|c|c|c|}
\hline \multicolumn{6}{|c|}{ LEVEL RECORDED/DETECTED } & \multicolumn{2}{|c|}{$\begin{array}{l}\text { Maximum } \\
\text { Permissible Limits }\end{array}$} \\
\hline Parameter & $\begin{array}{l}\text { Station } 1 \\
\bar{X} \pm \mathrm{SEM}^{*}\end{array}$ & $\begin{array}{l}\text { Station } 2 \\
\bar{X} \pm \text { SEM}^{*}\end{array}$ & $\begin{array}{l}\text { Station } 3 \\
\bar{X} \pm \text { SEM}^{*}\end{array}$ & $\begin{array}{l}\text { Station } 4 \\
\bar{X} \pm \text { SEM}^{*}\end{array}$ & $P$ - Value & FEPA** & SON*** \\
\hline $\begin{array}{l}\text { Water Temperature } \\
\left({ }^{\circ} \mathrm{C}\right)\end{array}$ & $\begin{array}{l}26.6 \pm 0.64^{\mathrm{a}} \\
(24.1-29.3)\end{array}$ & $\begin{array}{l}24.4 \pm 0.18^{\mathrm{b}} \\
(23.5-25.0)\end{array}$ & $\begin{array}{l}28.5 \pm 0.57^{\mathrm{c}} \\
(25.1-30.1)\end{array}$ & $\begin{array}{l}25.8 \pm 0.55^{\mathrm{d}} \\
(23.8-29.0)\end{array}$ & $p<0.05$ & $<40$ & Ambient \\
\hline $\mathrm{pH}$ & $\begin{array}{l}6.5 \pm 0.17 \\
(5.3-6.9)\end{array}$ & $\begin{array}{l}6.3 \pm 0.19 \\
(5.0-6.9)\end{array}$ & $\begin{array}{l}6.7 \pm 0.24 \\
(5.0-7.3)\end{array}$ & $\begin{array}{l}6.7 \pm 0.31 \\
(5.3-9.1)\end{array}$ & $p>0.05$ & $6.0-9.0$ & $6.5-8.5$ \\
\hline Turbidity (NTU) & $\begin{array}{l}67.5 \pm 3.65 \\
(50.0-84.0)\end{array}$ & $\begin{array}{l}94.7 \pm 25.6 \\
(51.2-321.0)\end{array}$ & $\begin{array}{l}80.8 \pm 16.03 \\
(6.8-197.0)\end{array}$ & $\begin{array}{l}79.3 \pm 15.9 \\
(6.8-197.0)\end{array}$ & $p>0.05$ & 10 & $\begin{array}{l}15 \\
\text { (TCU) }\end{array}$ \\
\hline $\begin{array}{l}\text { Conductivity } \\
(\mu \mathrm{S} / \mathrm{cm})\end{array}$ & $\begin{array}{l}25.8 \pm 1.12 \\
(20.1-29.3)\end{array}$ & $\begin{array}{l}23.9 \pm 2.41 \\
(3.5-28.4)\end{array}$ & $\begin{array}{l}31.1 \pm 1.52 \\
(24.1-41.0)\end{array}$ & $\begin{array}{l}35.3 \pm 7.10 \\
(22.8-98.0)\end{array}$ & $p>0.05$ & - & 1000 \\
\hline $\begin{array}{l}\text { Total Dis. Solids } \\
(\mathrm{Mg} / \mathrm{l})\end{array}$ & $\begin{array}{l}12.7 \pm 1.44 \\
(8.1-21.0)\end{array}$ & $\begin{array}{l}12.9 \pm 1.66 \\
(8.0-23.2)\end{array}$ & $\begin{array}{l}14.9 \pm 2.20 \\
(8.9-28.2)\end{array}$ & $\begin{array}{l}12.8 \pm 1.68 \\
(8.5-24.2)\end{array}$ & $p>0.05$ & 2000 & 500 \\
\hline $\begin{array}{l}\text { Total Susp. Solids } \\
(\mathrm{Mg} / \mathrm{l})\end{array}$ & $\begin{array}{l}8.2 \pm 1.14 \\
(5.4-15.0)\end{array}$ & $\begin{array}{l}19.5 \pm 1.3 \\
(5.4-110.0)\end{array}$ & $\begin{array}{l}43.5 \pm 31.5 \\
(6.0-324)\end{array}$ & $\begin{array}{l}30.1 \pm 17.9 \\
(5.7-184)\end{array}$ & & - & - \\
\hline $\begin{array}{l}\text { Dissolved Oxygen } \\
(\mathrm{Mg} / \mathrm{l})\end{array}$ & $\begin{array}{l}5.6 \pm 0.64 \\
(2.8-8.7)\end{array}$ & $\begin{array}{l}5.8 \pm 0.69 \\
(2.7-8.4)\end{array}$ & $\begin{array}{l}6.2 \pm 0.66 \\
(3.1-8.8)\end{array}$ & $\begin{array}{l}5.6 \pm 0.63 \\
(2.8-8.0)\end{array}$ & $p>0.05$ & $>5$ & - \\
\hline $\mathrm{BOD}_{5}(\mathrm{Mg} / \mathrm{l})$ & $\begin{array}{l}4.21 \pm 0.49 \\
(1.1-5.6)\end{array}$ & $\begin{array}{l}4.25 \pm 0.34 \\
(2.9-5.4)\end{array}$ & $\begin{array}{l}5.0 \pm 0.47 \\
(2.3-6.1)\end{array}$ & $\begin{array}{l}4.5 \pm 0.44 \\
(2.0-5.6)\end{array}$ & $p>0.05$ & $<10$ & - \\
\hline $\begin{array}{l}\text { Chem. Oxygen } \\
\text { Demand (Mg/l) }\end{array}$ & $\begin{array}{l}4.8 \pm 0.42 \\
(2.0-6.4)\end{array}$ & $\begin{array}{l}4.9 \pm 0.40 \\
(2.3-6.4)\end{array}$ & $\begin{array}{l}5.5 \pm 0.42 \\
(2.9-7.0)\end{array}$ & $\begin{array}{l}4.8 \pm 0.42 \\
(2.3-6.5)\end{array}$ & $p>0.05$ & & \\
\hline Phosphate $(\mathrm{Mg} / \mathrm{l})$ & $\begin{array}{l}10.1 \pm 6.92 \\
(2.3-72.3)\end{array}$ & $\begin{array}{l}11.7 \pm 6.81 \\
(2.3-72.0)\end{array}$ & $\begin{array}{l}12.9 \pm 7.50 \\
(3.2-79.8)\end{array}$ & $\begin{array}{l}11.7 \pm 6.95 \\
(2.3-73.4)\end{array}$ & $p>0.05$ & 5 & - \\
\hline Nitrate $(\mathrm{Mg} / \mathrm{l})$ & $\begin{array}{l}57.7 \pm 4.76 \\
(35.2-77.6)\end{array}$ & $\begin{array}{l}55.4 \pm 6.63 \\
(7.4-76.9)\end{array}$ & $\begin{array}{l}63.9 \pm 3.97 \\
(46.0-79.8)\end{array}$ & $\begin{array}{l}59.2 \pm 4.25 \\
(42.5-77.5)\end{array}$ & $p>0.05$ & 20 & 50 \\
\hline Sulphate $(\mathrm{Mg} / \mathrm{l})$ & $\begin{array}{l}57.5 \pm 4.64 \\
(30.1-77.0)\end{array}$ & $\begin{array}{l}65.3 \pm 4.83 \\
(45.2-85.1) \\
\end{array}$ & $\begin{array}{l}73.8 \pm 7.30 \\
(48.9-120.0) \\
\end{array}$ & $\begin{array}{l}67.1 \pm 5.53 \\
(46.5-95.0) \\
\end{array}$ & $p>0.05$ & $200-400$ & 100 \\
\hline
\end{tabular}

$\mathrm{a}, \mathrm{b}, \mathrm{c}, \mathrm{d}=$ Means with different superscripts across the rows are significantly different at $\mathrm{p}<0.05$ *Standard Error of Mean.

**Nigerian Water Quality Standard for Inland Surface Water, Federal Environmental Protection Agency (FEPA), 2003.

***Nigerian Standard for Drinking Water Quality, Standards Organisation of Nigeria (SON), 2007

The $\mathrm{pH}$ values revealed that the water was moderately acidic to moderately alkaline with a range of 5.0 to 9.1 (Fig. $3)$. Some of the $\mathrm{pH}$ values are either lower or higher than the acceptable limits set by both FEPA (2003) and SON (2007).

The turbidity values ranged from 6.8 321.0 NTU. The mean turbidity values showed a spatial variation, Station 2 had the highest values, followed by Stations
3, 4 and 1 being the least (Fig. 4). Most of the turbidity values exceeded acceptable limits of 10NTU and 15NTU, set by FEPA (2003) and SON (2007) respectively.

The electrical conductivity values ranged from $3.5-98.0 \mu \mathrm{S} / \mathrm{cm}$; the highest value was recorded in station 4 in April 2015 (Fig. 5). All the conductivity values recorded in this study are within the acceptable limits. 
The total dissolved solids values ranged from $8.0-28.2 \mathrm{mg} / \mathrm{l}$. The highest value was recorded in station 3 in April 2015 (Fig. 6). All the TDS values recorded were within the acceptable limits of $2000 \mathrm{mg} / \mathrm{l}$ and $500 \mathrm{mg} / \mathrm{l}$ set by FEPA (2003) and SON (2007) respectively.

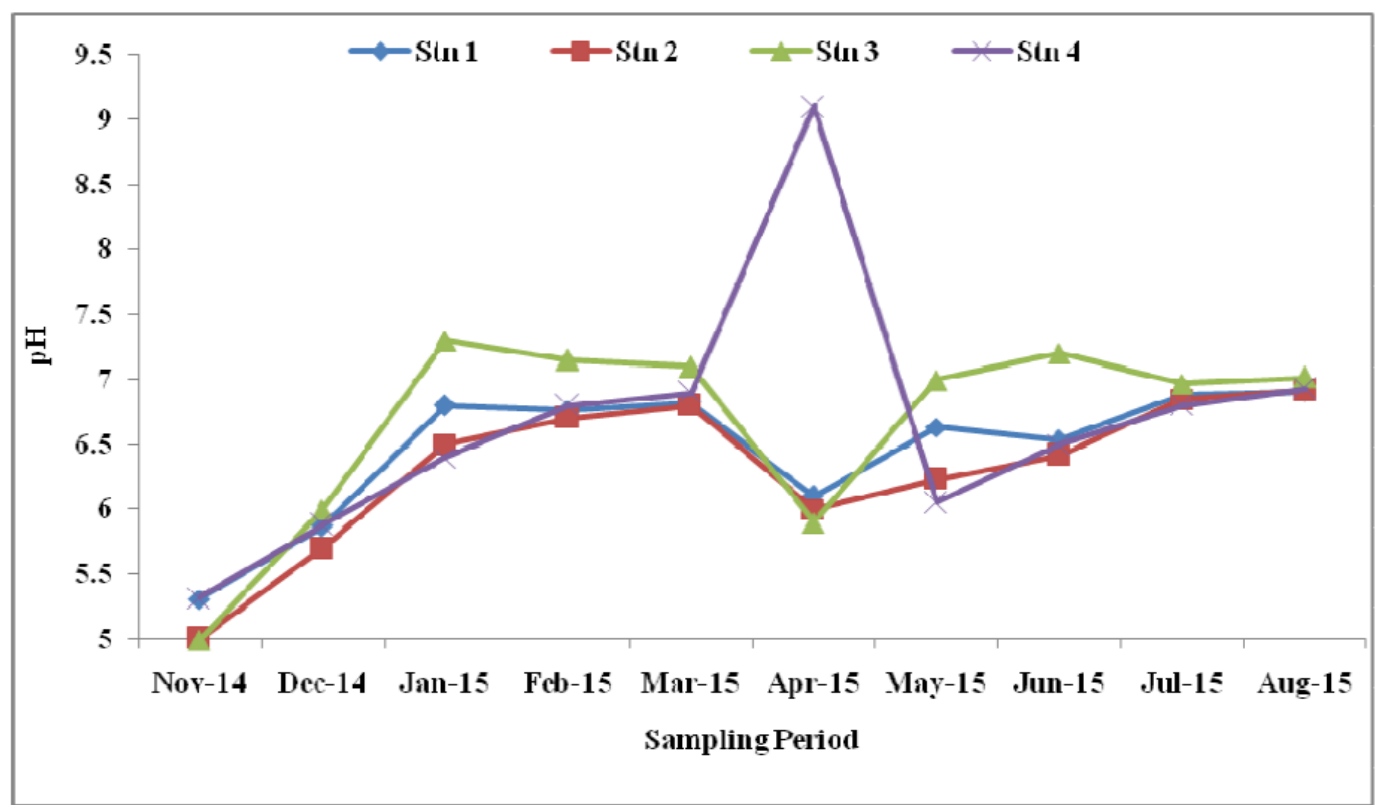

Fig. 3: Spatial and temporal variations in $\mathrm{pH}$ at the study stations in Aba River

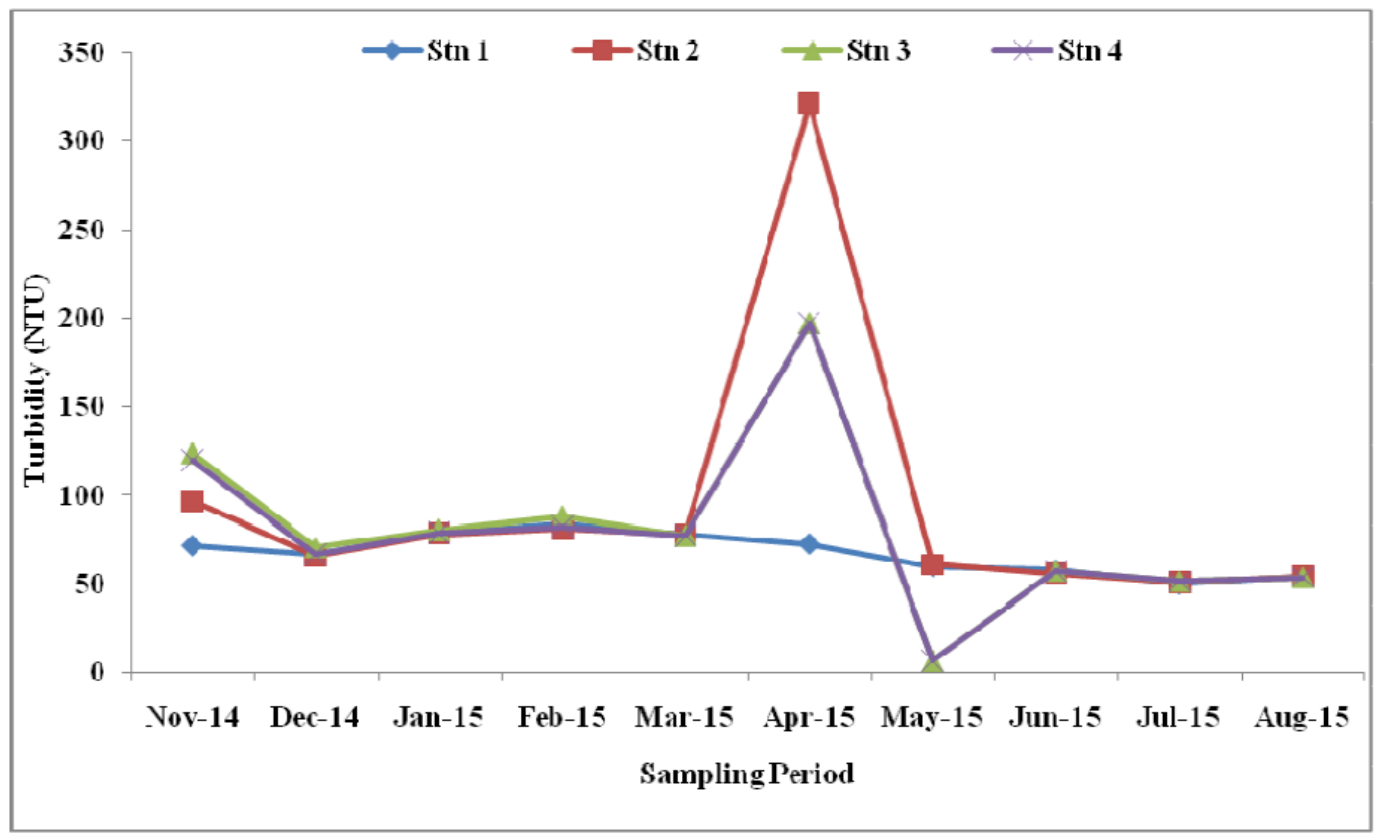

Fig. 4: Spatial and temporal variations in Turbidity at the study stations in Aba River 


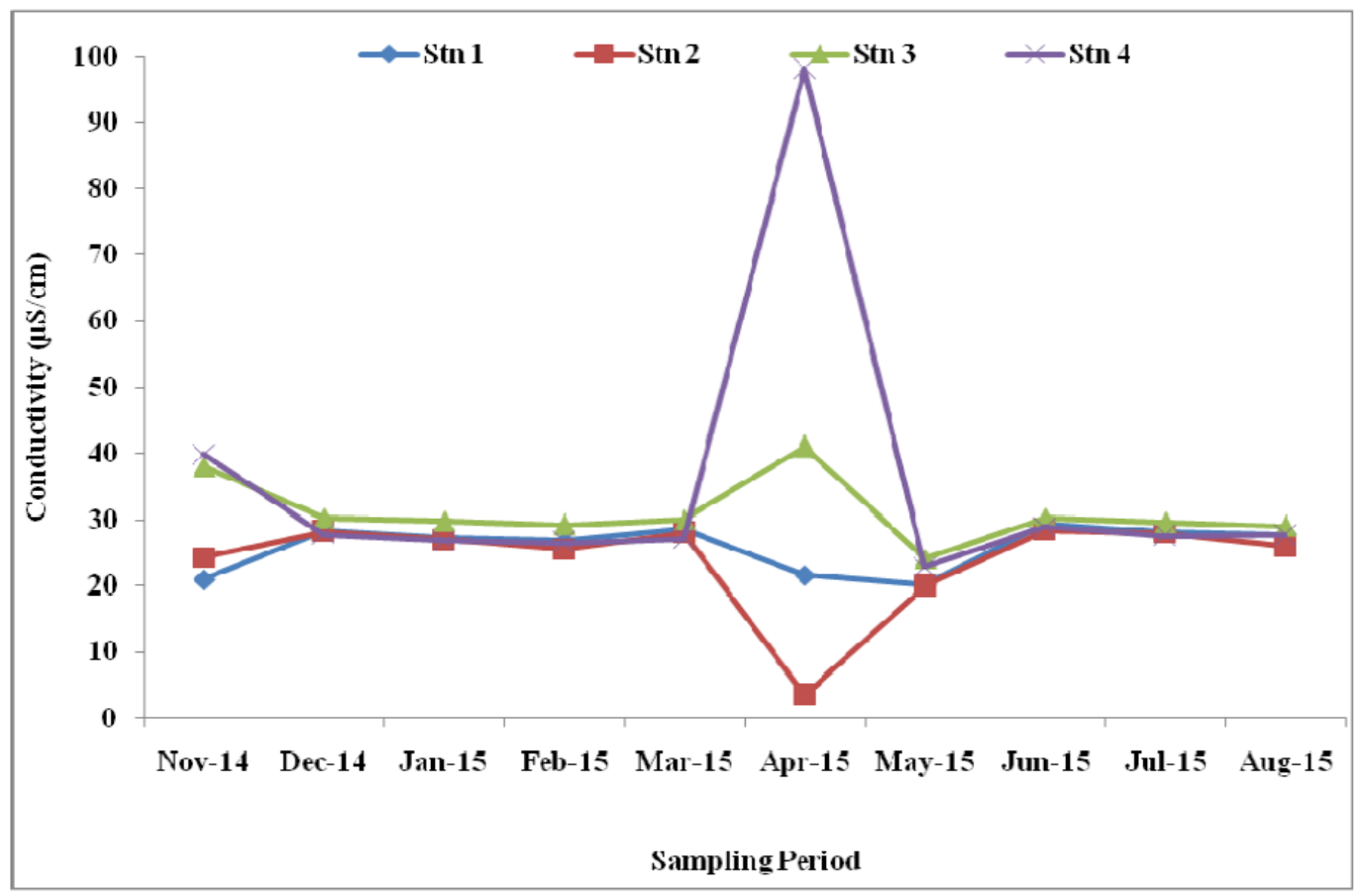

Fig. 5: Spatial and temporal variations in Conductivity at the study stations in Aba River

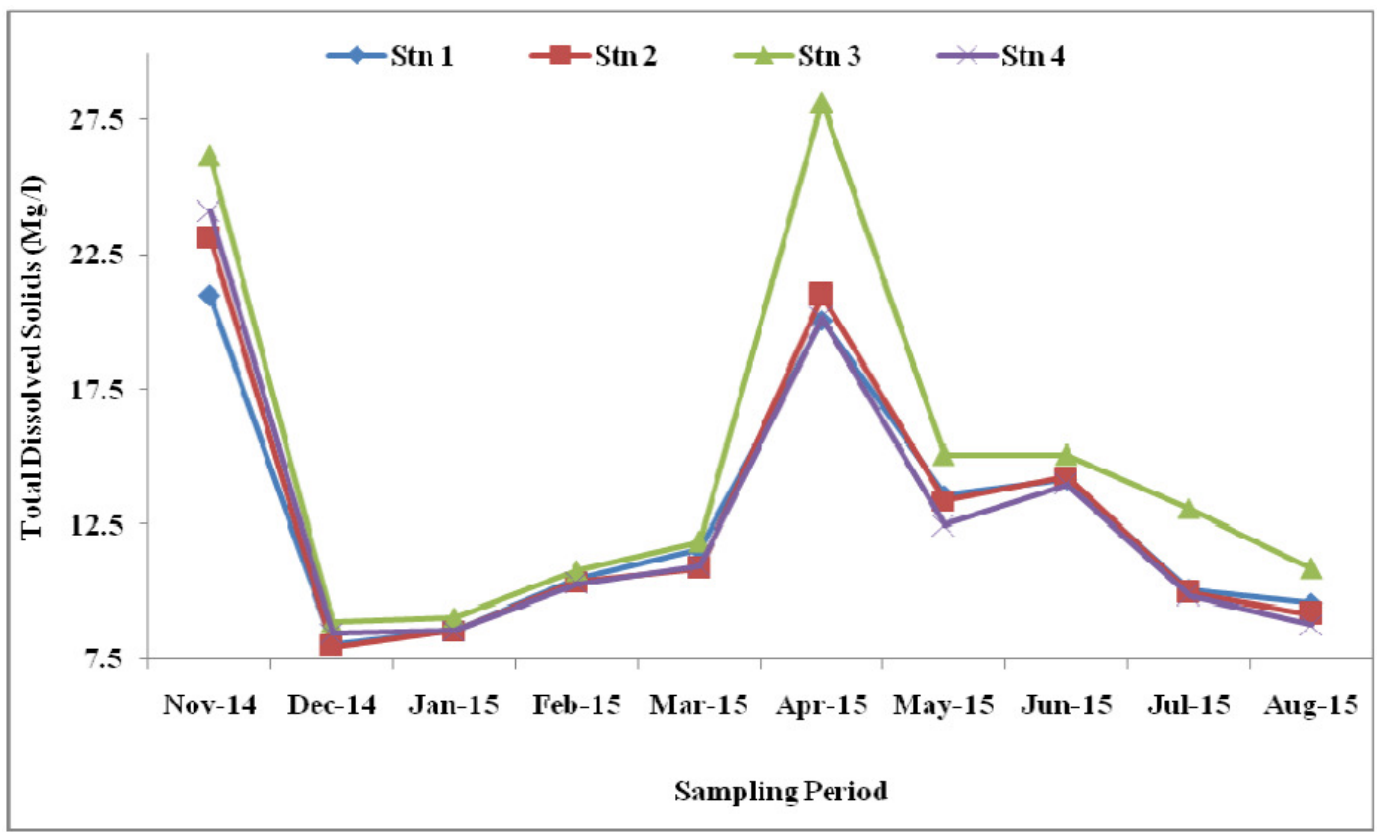

Fig. 6: Spatial and temporal variations in Total Dissolved Solids at the study stations in Aba River

The total suspended solids values ranged from $5.4-324.0 \mathrm{mg} / \mathrm{l}$. The highest value was recorded in station 3 in April 2015 (Fig. 7). 
The dissolved oxygen values ranged from $2.7-8.8 \mathrm{mg} / \mathrm{l}$. The lowest and highest values were recorded in stations 2 and 3 in December 2014 and February 2015 respectively (Fig. 8).

The Biochemical oxygen demand values ranged between 1.1 and $6.1 \mathrm{mg} / \mathrm{l}$. The highest value was recorded at station 3 in May 2015 (Fig. 9). The lowest mean BOD value $(4.21 \mathrm{mg} / \mathrm{l})$ was recorded in station 1; others were station $2(4.25 \mathrm{mg} / \mathrm{l})$, station $4(4.5 \mathrm{mg} / \mathrm{l})$ and station 3 (5.0).

The Chemical Oxygen Demand (COD) values recorded ranged between
2.0 and $7.0 \mathrm{mg} / \mathrm{l}$. The highest value was recorded at station 3 in March 2015 (Fig. 10). The lowest mean COD values $(4.8 \mathrm{mg} / \mathrm{l})$ were recorded in stations 1 and 4 ; others are station $2(4.9 \mathrm{mg} / \mathrm{l})$ and station $3(5.5 \mathrm{mg} / \mathrm{l})$. The phosphate values ranged between 2.3 and $79.8 \mathrm{mg} / \mathrm{l}$. The highest value was recorded in December 2014 in station 3 (Fig. 11). The lowest and highest mean values of 10.1 and $12.9 \mathrm{mg} / \mathrm{l}$ were recorded in stations 1 and 3 respectively. Most of the values exceeded acceptable limits set by FEPA.

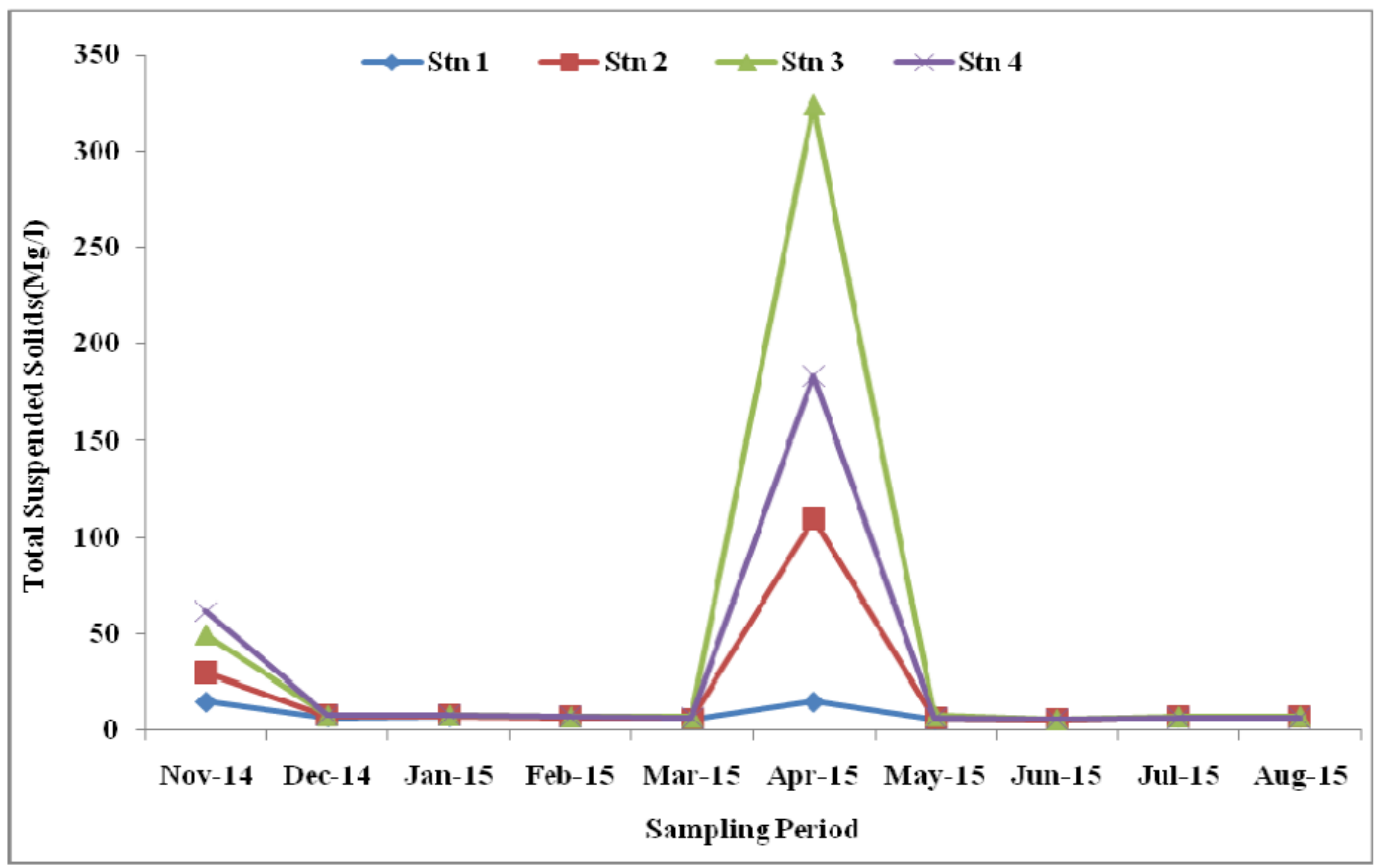

Fig. 7: Spatial and temporal variations in Total Suspended Solids at the study stations in Aba River 


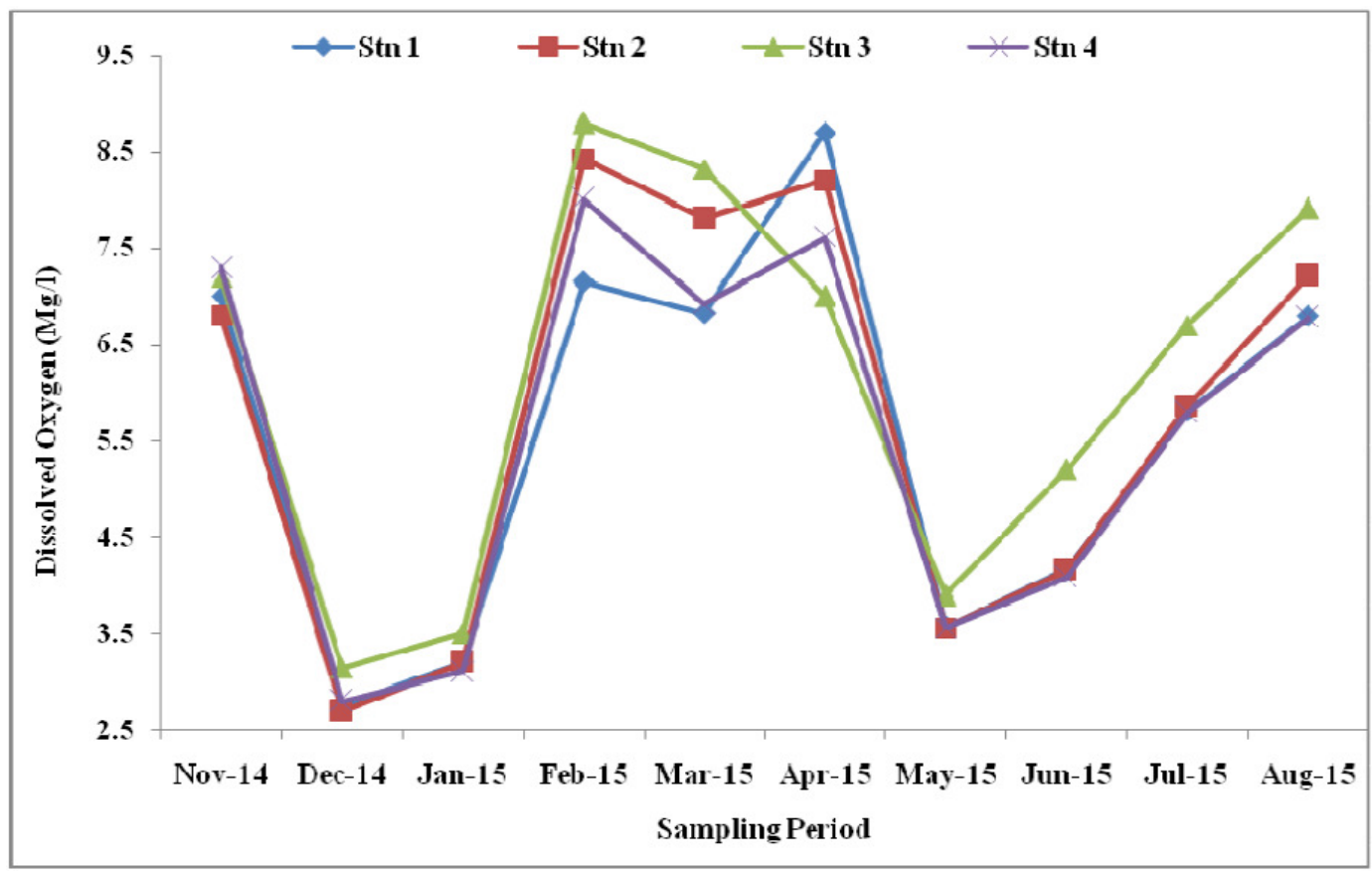

Fig. 8: Spatial and temporal variations in Dissolved Oxygen at the study stations in Aba River

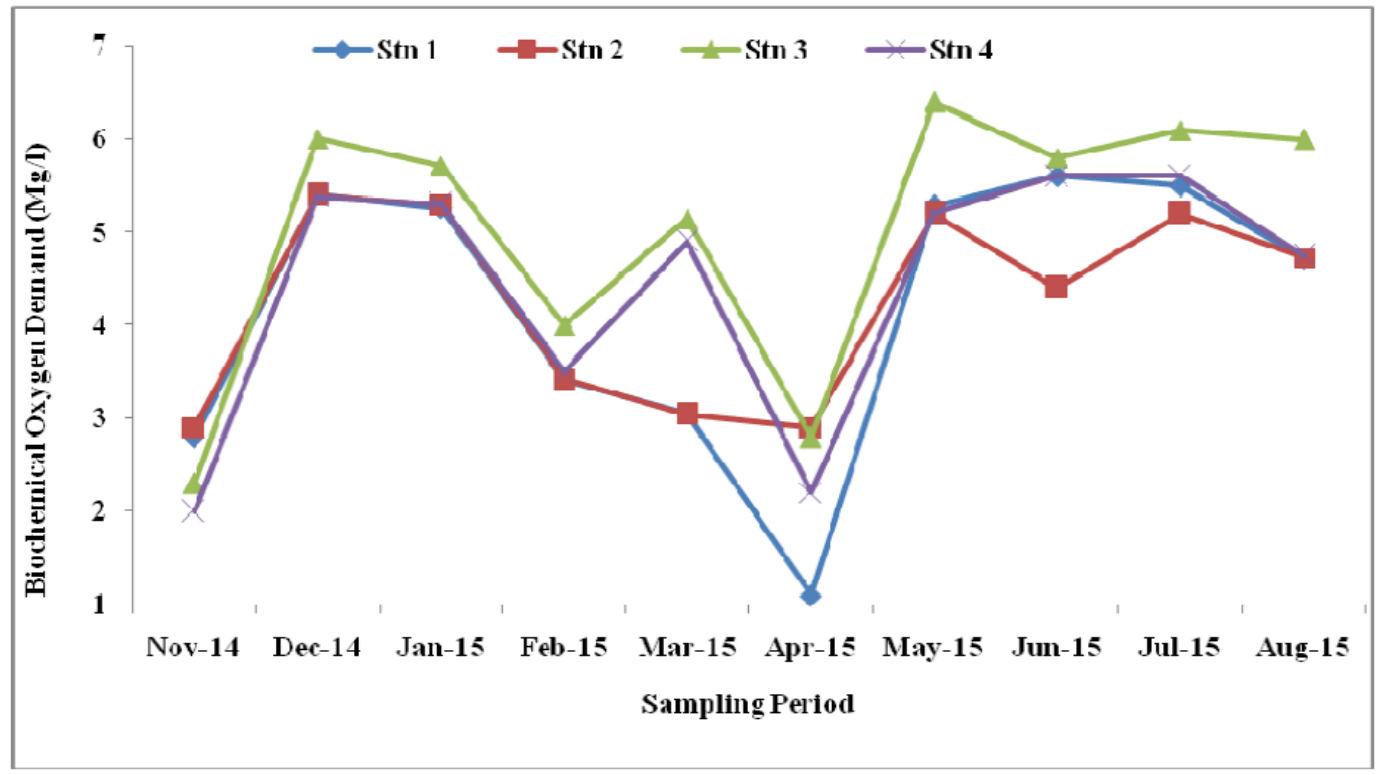

Fig. 9: Spatial and temporal variations in Biochemical Oxygen Demand at the study stations in Aba River 


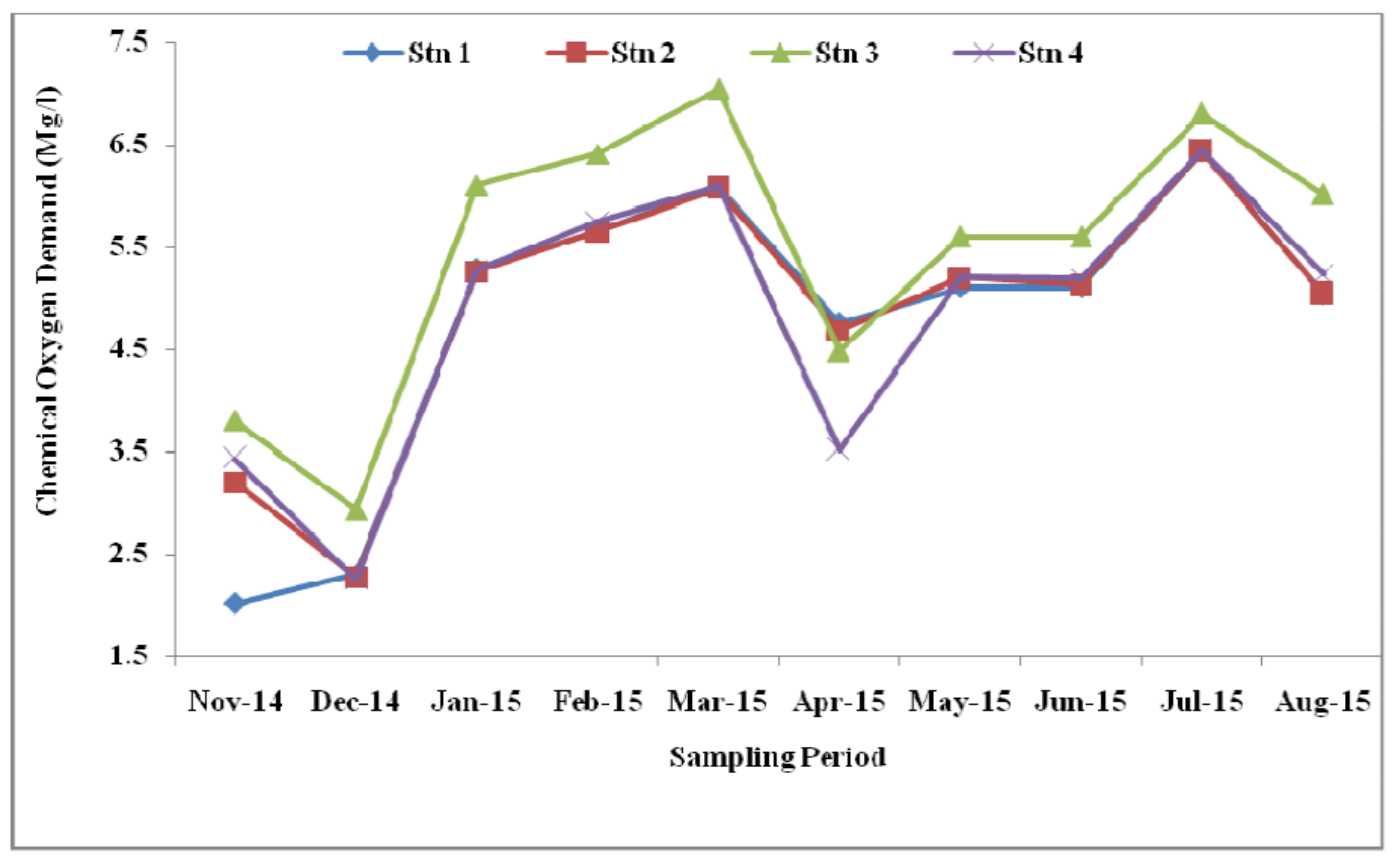

Fig. 10: Spatial and temporal variations in Chemical Oxygen Demand at the study stations in Aba River

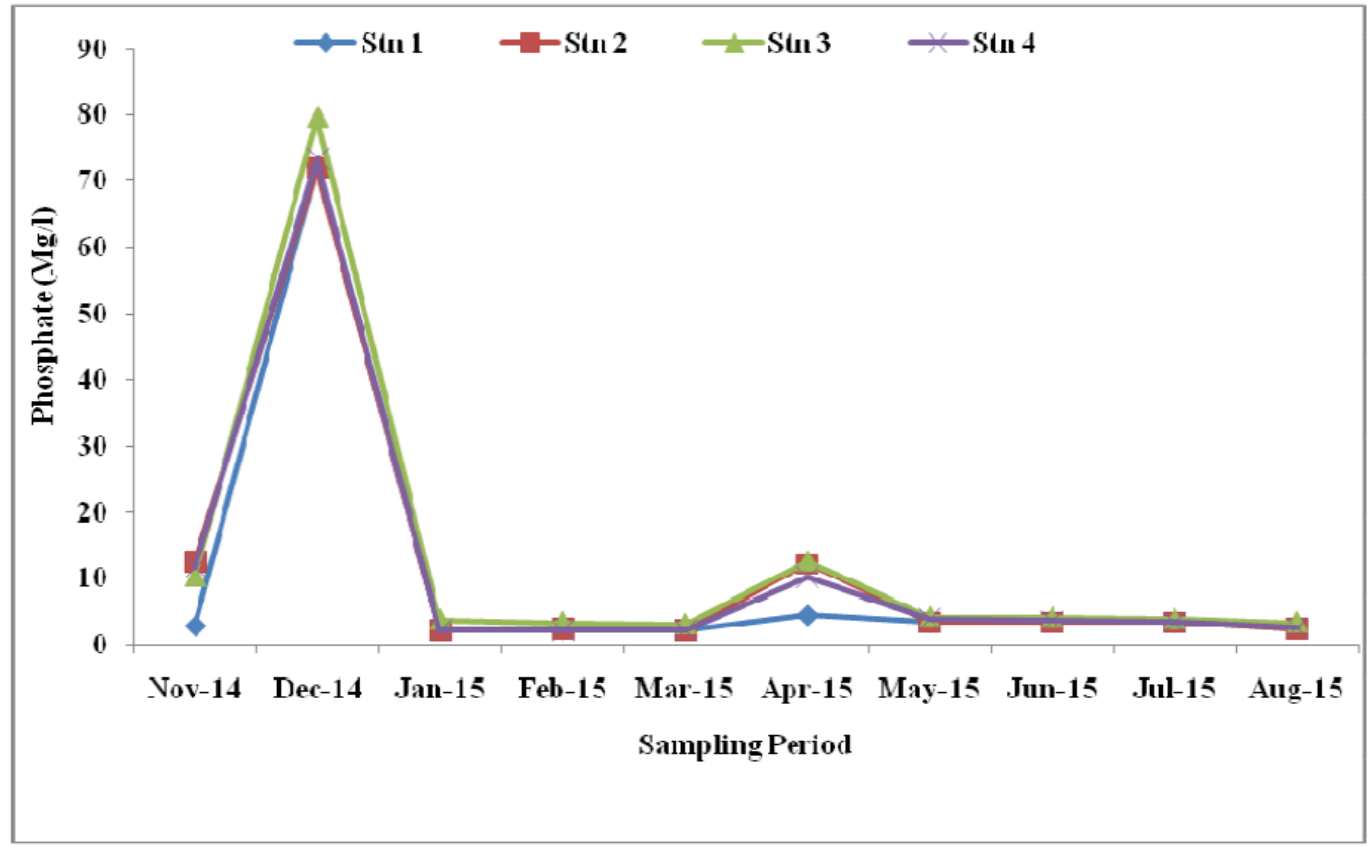

Fig. 11: Spatial and temporal variations in Phosphate at the study stations in Aba River

The nitrate values ranged from $7.4-$ $79.8 \mathrm{mg} / \mathrm{l}$. The highest value was recorded in August 2015 in station 3 (Fig. 12). The lowest and highest mean values of 55.5 and $63.9 \mathrm{mg} / \mathrm{l}$ were recorded in stations 2 and 3 respectively. Most of the values exceeded acceptable limits set by FEPA and SON. 
The sulphate values ranged from 30.1 - $120 \mathrm{mg} / \mathrm{l}$. The highest value was recorded in April 2015 in station 3 (Fig.
13). The lowest and highest mean values of 57.5 and $73.8 \mathrm{mg} / \mathrm{l}$ were recorded in stations 1 and 3 respectively.

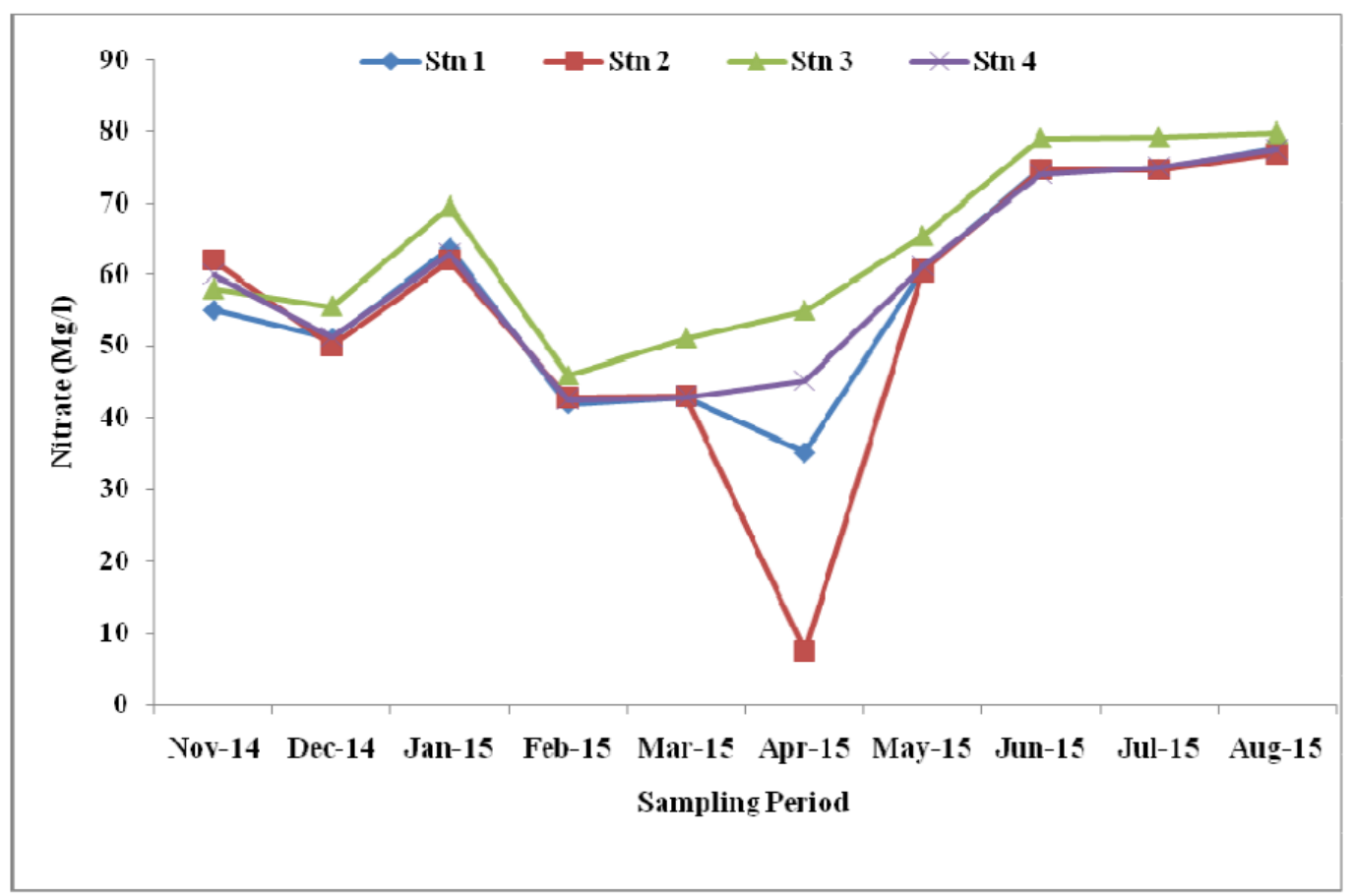

Fig. 12: Spatial and temporal variations in Nitrate at the study stations in Aba River

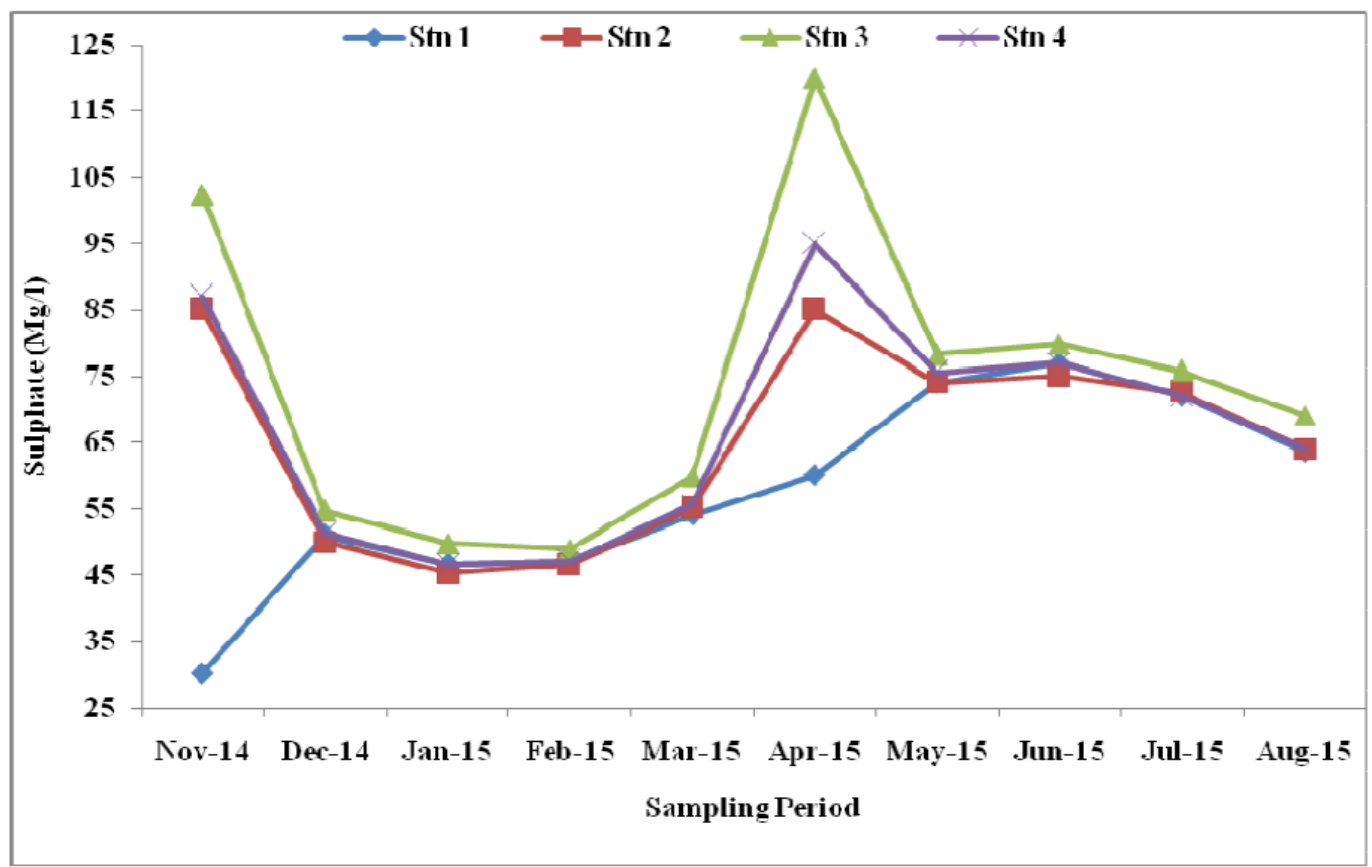

Fig. 13: Spatial and temporal variations in Sulphate at the study stations in Aba River 


\section{Discussion}

This study on the anthropogenic impact on the water quality of Aba River, southeast Nigeria has considered the different activities going on around the river. The variations in the physical and chemical parameters of the Aba River showed that like most Nigerian inland waters, it is influenced by external factors as well as interactions between the various facet of its hydrology and biology. The physico-chemical parameters of Aba River did not show seasonal variations. The variations in time and space as regards water temperature were primarily influenced by the climatic factors, the time of sampling and human activities. The water temperature trend showed that the values were generally higher in Station 3 and could be attributed to the effluents of high temperature discharged from the abattoir. Related studies recorded water temperatures close to this range or slightly higher. Eni et al. (2014) recorded water temperature values of 25.4 to $27.2^{\circ} \mathrm{C}$ in Obot Okoho Stream, Nassarawa village, Calabar, Nigeria while Ubwa et al. (2013) and Osibanjo and Adie (2007) recorded slightly higher values of 30.2 to $30.8^{\circ} \mathrm{C}$ and 31.0 to $34.0^{\circ} \mathrm{C}$ in a stream in Gboko, Nigeria and Oshunkaye stream in Ibadan City, Nigeria respectively. Temperature influences the amount of dissolved oxygen in water which in turn influences the survival of aquatic organisms (Ubwa et al., 2013).

The $\mathrm{pH}$ values recorded in this study could not be attributed to the effect of the abattoir effluent alone because $\mathrm{pH}$ exhibited the same trend throughout the study. Extremes of $\mathrm{pH}$ value recorded in stations 3 and 4 in April 2015 could be attributed to a combined impact of dredging activity carried out within that section of the river during the period and cumulative impact. Ohimain et al. (2008) and Seiyaboh et al. (2013) reported that dredging lowers the $\mathrm{pH}$ of water bodies while Radojevic and Bashkin (1999) observed that extremes of $\mathrm{pH}$ are associated with polluted surface waters. Clarke (1994) observed that in some cases, the most ecologically devastating environmental effects and subsequent social consequences may result not from direct effects of a particular action, project, or activity but from the combination of existing stresses and the individually minor effects of multiple actions over time.

The highest turbidity was recorded in station 2 in April 2015 while relatively high values were also recorded in stations 3 and 4 in April 2015. The turbidity value recorded in station 2 in April 2015 could be attributed to washing of cars, and rug carpets. Aikins and Boakye (2015) observed the carwash wastewater contribute to high turbidity in the receiving water body. The values recorded in stations 3 and 4 could be attributed to the impact of dredging in that section of the river. Ohimain et al. (2008), Seiyaboh et al. (2013) and IADC (2015) reported that dredging increases turbidity in a river downstream of the dredged section. Abattoir effluent also affects turbidity of the receiving water body (Ojo, 2014). The high levels of turbidity observed in the Aba River could also affect fish and other aquatic life due to obstruction of light (Izonfuo and Bariweni, 2001).

The relatively higher electrical conductivity values recorded in stations 3 and 4 in April 2015 could be attributed to 
the impact of the dredging carried out in that section of the river during that period (Seiyaboh et al., 2013; Rehman et al., 2016); lower values were recorded in the study outside April 2015. Abattoir effluent also impact on the downstream electrical conductivity of a receiving water body (Eni et al., 2014). The conductivity of most freshwaters ranges from 10 to $1,000 \mu \mathrm{S} / \mathrm{cm}$ but may exceed $1,000 \mu \mathrm{S} / \mathrm{cm}$, especially in polluted waters, or those receiving large quantities of land run-off (Chapman, 1996).

The highest total dissolved solids (TDS) value was recorded in station 3 in April 2015. The values of TDS followed the same trend in all the stations in April 2015, which could be attributed to a cumulative impact (Clarke, 1994), rather than abattoir effluent and dredging. Studies have shown that car wash, abattoir effluents and dredging seriously impact on the TDS of the receiving water bodies (Ohimain et al., 2008; Seiyaboh et al., 2013; Ubwa et al., 2013; Eni et al., 2014; Aikins and Boakye, 2015).

The Total Suspended Solids values recorded in this study was highest in stations 3 in April 2015 and followed the same trend in all the stations as TDS. This could also be attributed to a cumulative impact rather than abattoir effluent and dredging. Studies have also shown like in TDS, that car wash, abattoir effluents and dredging seriously impact on the TSS of the receiving water bodies (Ohimain et al., 2008; Seiyaboh et al., 2013; Ubwa et al., 2013; Danha et al., 2014; Eni et al., 2014; Aikins and Boakye, 2015).

The lowest Dissolved Oxygen (DO) values were recorded in stations 3 and 2 in February 2015 and December 2014 respectively. The low DO values
$(<5 \mathrm{mg} / \mathrm{l})$ recorded in December 2014, January, May and June 2015 (stations 1, 2 and 4) could be attributed to cumulative impact because DO values in this study showed the same trend in all the stations. The value recorded in station 3 could be attributed to abattoir effluent and was in line with related studies (Ubwa et al., 2013; Eni et al., 2014). According to Chapman (1996), concentrations below 5mg/l may adversely affect the functioning and survival of biological communities and below $2 \mathrm{mg} / \mathrm{l}$ may lead to the death of most fish.

The highest Biochemical Oxygen Demand (BOD) value was recorded in stations 3 in May 2015. The BOD values were generally higher throughout the study in station 3 except in November 2014 and April 2015; this could be attributed to the high organic contents of abattoir effluent released in the station. Studies have shown that abattoir effluents impact seriously on BOD values of the receiving water bodies (Omole and Longe, 2008; Ubwa et al., 2013). According to Chapman (1996), unpolluted waters typically have BOD values of $2 \mathrm{mg} / \mathrm{l}$ or less, whereas those receiving wastewaters may have values up to $10 \mathrm{mg} / \mathrm{l}$ or more, particularly near to the point of wastewater discharge.

The highest Chemical Oxygen Demand (COD) value was recorded at station 3 in March 2015. The trend observed in the COD values is similar to that of BOD; station 3 generally recorded higher values throughout the study except in April 2015 when the river was dredged. The values recorded in this study were quite low compared to related studies elsewhere. Omole and longe (2008) recorded values of 425.0 - 1675 
$\mathrm{mg} / \mathrm{l}$ in Illo River, Ota and Ubwa et al. (2013) recorded values of $444.0-1508$ $\mathrm{mg} / \mathrm{l}$ in a stream in Gboko all in Nigeria. The concentrations of COD observed in surface waters range from $20 \mathrm{mg} / \mathrm{l}$ or less in unpolluted waters to greater than 200 $\mathrm{mg} / \mathrm{l}$ in waters receiving effluents (Chapman, 1996).

The highest Phosphate value was recorded in December 2014 in station 3. Phosphate values followed the same trend in all the stations throughout the study and could be attributed to cumulative impact (Clarke, 1994). The phosphate values recorded in this study were generally low compared to Osibanjo and Adie (2007) that recorded higher values of $142-180 \mathrm{mg} / \mathrm{l}$ in Oshunkaye stream in Ibadan City, Nigeria. Phosphate is rarely found in high concentrations in freshwaters as it is actively taken up by plants. As a result there can be considerable seasonal fluctuations in concentrations in surface waters. In most natural surface waters, phosphate ranges from 0.005 to $0.020 \mathrm{mg} / \mathrm{l}$ (Chapman, 1996).

The highest nitrate value of was recorded in August 2015 (station 3) and were generally higher in station 3 throughout the study, which could be attributed the effect of abattoir effluent. Ubwa et al. (2013) recorded values within the same range $(9.30-68.0 \mathrm{mg} / \mathrm{l})$ in a stream in Gboko, Nigeria while Osibanjo and Adie (2007) recorded higher values $(62-159 \mathrm{mg} / \mathrm{l})$ in Oshunkaye stream in Ibadan City, Nigeria. According to Chapman (1996), when influenced by human activities, surface waters can have nitrate concentrations up to $5 \mathrm{mg} / \mathrm{l}$, but often less than $1 \mathrm{mg} / 1$. Concentrations in excess of
$5 \mathrm{mg} / \mathrm{l}$ usually indicate pollution by human or animal waste, or fertiliser runoff.

The highest sulphate value was recorded in April 2015 (station 3). This could be attributed to combined effect of the abattoir effluent and dredging activity carried out during the period (Ohimain $e t$ al., 2008; Ubwa et al., 2013). Sulphate concentrations in natural waters are usually between 2 and $80 \mathrm{mg} / \mathrm{l}$, although they may exceed $1,000 \mathrm{mg} / \mathrm{l}$ near industrial discharges or in arid regions where sulphate minerals, such as gypsum, are present. High concentrations $(>400 \mathrm{mg} / \mathrm{l}$ ) may make water unpleasant to drink (Chapman, 1996).

\section{Conclusion}

A number of major anthropogenic activities were identified; these activities and other salient activities in the watershed have individually and cumulatively impacted on the water quality of Aba River. Some of the water quality parameters had elevated values but the most affected were turbidity (6.8 - 321NTU/FEPA, 10NTU), phosphate $(2.3-79.8 \mathrm{mg} / \mathrm{l} / \mathrm{FEPA}, 5 \mathrm{mg} / \mathrm{l})$ and nitrate (7.4 - 79.8mg/l/FEPA, 20mg/l). These observed impacts on the water quality have directly or indirectly affected the ecological, domestic and other uses of the river. Residents cannot use the water for drinking, cooking, industrial or aquaculture purposes.

\section{Acknowledgments}

We sincerely appreciate Mr. Chinedu Ogbodo of Department of Geography, University of Nigeria, Nsukka, Nigeria for producing the study map. 


\section{References}

Aikins, S. and Boakye, D.O. (2015). Carwash Wastewater Characterization and Effect on Surface Water Quality: A Case Study of Washing Bays Sited on Oda and Daban Streams in Kumasi, Ghana. ARPN Journal of Science and Technology, 5(4): 190 - 197.

American Public Health Association (APHA) (1998). Standard methods for exanimation of water and wastewater. 20th Ed. American Public Health Association, Washington, D.C. 1193pp.

Anyanwu, E.D. (2012). PhysicoChemical and Some Trace Metal Analysis of Ogba River, Benin City, Nigeria. Jordan Journal of Biological Sciences, 5(1): 47 - 54

Arimoro, F.O. (2009). Impact of rubber effluent discharges on the water quality and macroinvertebrate community assemblages in a forest stream in the Niger Delta, Nigeria. Chemosphere, 77, 440-449.

Chapman, D. (ed.) (1996). Water Quality Assessment. A Guide to the use of Biota, Sediments and Water in Environmental Monitoring ( $2^{\text {nd }}$ Edition). Taylor and Francis, London and New York. 626pp.

Clarke, R. (1994). Cumulative Effects Assessment: A tool for sustainable development. Impact Assessment. Impact Assessment Bulletin, 12:313 $-331$.

Danha, C., Utete, B., Soropa, G. and Rufasha, S.B. (2014). Potential Impact of Wash Bay Effluent on the Water Quality of a Subtropical River. Journal of Water Resource and Protection, 6:1045-1050
Eni, D.I., Etu, S.J. and Oka, P.O. (2014). The effect of abattoir discharge on the Obot Okoho Stream quality in Nassarawa village, Calabar, Nigeria. Asian Journal of Science and Technology, 5(8): 501-507.

Federal Environmental Protection Agency (FEPA) (2003). Guidelines and Standards for Environmental Pollution Control in Nigeria. 238 pp.

Gilbert, C.S. and Wendy, A.T. (2003). Watershed scale assessment of nitrogen and phosphorus loadings in the Indian River Lagoon Basin, Florida. Environmental Management, 67:363-372

Hillel, N., Geyer, S., Licha, T., Khayat, S., Laronne, J.B. and Siebert, C. (2015). Water quality and discharge of the Lower Jordan River. Journal of Hydrology, 527:1096 - 1105.

IADC (2015). Facts about turbidity \& dredging - An Information Update from the IADC. International Association of Dredging Companies. Www.iadcdredging.com. Accessed $2^{\text {nd }}$ November 2016.

Izonfuo, L.W.A. and Bariweni, A.P. (2001). The Effect of Urban Runoff Water and Human Activities on Some Physico-Chemical Parameters of the Epie Creek in The Niger Delta. J. Appl. Sci. Environ. Mgt., 5:47 - 55.

Jaji, M., Bamgbose, O.O., Odukoya, O.O. and Arowolo, T.A. (2007). Water quality assessment of Ogun River, South West Nigeria. Environ. Monit. Assess., 133:473 482.

Kunwar, P.S., Amrita, M and Sarita, S. (2005). Water quality assessment 
and apportionment of pollution sources of Gomti River (India) using multivariate statistical techniques-a case study. Analytica Chimica Acta, 538: 355-374.

May, AM., Mutasem, E., Mark, D.S. and Lester, J.N. (2006). Factors influencing development of management strategies for the Abou Ali River in Lebanon II: Seasonal and annual variation. Science of the Total Environment, 362(1): 31 - 41.

Ogbeibu, A.E. (2005). Biostatistics - A practical approach to Research and Data Handling. Mindex Publishing Company Limited, Benin City, Nigeria. 264pp.

Ohimain, E.I., Imoobe, T.O. and Bawo, D.D.S. (2008. Changes in Water Physico-Chemical Properties Following the Dredging of an Oil Well Access Canal in the Niger Delta. World Journal of Agricultural Sciences, 4(6):752758.

Ojo, J.O. (2014). Environmental Impact Assessment of Effluents from OkoOba Municipal Abattoir at Agege, Lagos State, Nigeria. Global Advanced Research Journal of Agricultural Science, 3(10):317320.

Omole, D.O. and Longe, E.O. (2008). An assessment of the impact of abattoir effluent on River Illo, Ota, Nigeria. Journal of Environmental Science and Technology, 1(2):56 - 64.

Osibanjo, O. and Adie, G.U. (2007). Impact of effluent form Bodija Abattoir on the physiochemical of Oshunkaye stream, Ibadan City, Nigeria. African Journal of Biotechnology, 6(15):1806-1811.
Osibanjo, O., Daso, P.A. and Gbadebo, M.A. (2011). The Impact of Industries on Surface Water Quality of River Ona and River Alaro in Oluyole Industrial Estate, Ibadan, Nigeria. African Journal of Biotechnology, 10(4):696-702.

Radojevic, M and Bashkin, V.N. (1999). Practical Environmental Analysis. Royal Society of Chemistry, Cambridge, UK. 466pp.

Rehman, M., Yousuf, A.R., Balkhi, M.H., Rather, M.I., Shahi, N., Meraj, M. and Hassan, K. (2016). Dredging induced changes in zooplankton community and water quality in Dal Lake, Kashmir, India. African Journal of Environmental Science and Technology, 10(5):141149.

Seiyaboh, E.I., Ogamba, E.N. and Utibe, D.I. (2013). Impact of Dredging on the water quality of Igbedi Creek, Upper Nun River, Niger Delta, Nigeria. IOSR Journal of Environmental Science, Toxicology and Food Technology, 7(5):51 - 56.

Standards Organisation of Nigeria (2007). Nigerian standard for drinking water quality. Nigerian Industrial Standard (NIS 554). Standards Organisation of Nigeria (SON), Abuja, Nigeria. pp. $14-17$.

Ubwa, S.T., Atoo, G.H., Offem, J.O., Abah, J. and Asemave, K. (2013). An assessment of surface water pollution status around Gboko abattoir. African Journal of Pure and Applied Chemistry, 7(3):131138.

Wang, X., Lu, Y., Han, J., He, G. and Wang, T. (2007). Identification of anthropogenic influences on water quality of rivers in Taihu 
watershed. Journal of Environmental Sciences, 19:475481.

World Bank (1995). Nigeria Strategic Options for Redressing Industrial Pollution. World Bank, Industry and Energy Division. $1^{\text {st }}$ Edn. West Central Africa Department, Annexes, pp: $60-62$.

Yu, S. and Shang, J. (2003). Factor analysis and dynamics of water quality of the Songhua River, Northeast China. Water Air Soil Pollut., 144:159-169.

Zhai, X., Xia, J. and Zhang, Y. (2014). Water quality variation in highly disturbed Huai River Basin, China from 1994 - 2005 by multistatistical analyses. Science of the Total Environment, 496: 594 - 606. 